\title{
Identifying Decisive Socio-Political Sustainability Barriers in the Supply Chain of Banking Sector in India: Causality Analysis Using ISM and MICMAC
}

\author{
Wen-Kuo Chen ${ }^{1}$, Venkateswarlu Nalluri ${ }^{2}$, Man-Li Lin ${ }^{3}$ and Ching-Torng Lin ${ }^{2, *}$ \\ 1 Department of Marketing and Logistic Management, College of Management, Chaoyang University of \\ Technology, Taichung 413310, Taiwan; wkchen@cyut.edu.tw \\ 2 College of Management, Da-Yeh University, Changhua 51591, Taiwan; nallurivenkey7@gmail.com \\ 3 Department of Finance, National Changhua University of Education, Changhua 50074, Taiwan; \\ lily@eim.com.tw \\ * Correspondence: charllin@mail.dyu.edu.tw
}

Citation: Chen, W.-K.; Nalluri, V.; Lin, M.-L.; Lin, C.-T. Identifying Decisive Socio-Political Sustainability Barriers in the Supply Chain of Banking Sector in India: Causality Analysis Using ISM and MICMAC. Mathematics 2021, 9, 240. https:// doi.org/10.3390/math9030240

Academic Editor: José Antonio Filipe Received: 11 December 2020

Accepted: 22 January 2021

Published: 26 January 2021

Publisher's Note: MDPI stays neutral with regard to jurisdictional claims in published maps and institutional affiliations.

Copyright: (c) 2021 by the authors. Licensee MDPI, Basel, Switzerland. This article is an open access article distributed under the terms and conditions of the Creative Commons Attribution (CC BY) license (https:// creativecommons.org/licenses/by/ $4.0 /)$.

\begin{abstract}
The banking sector often plays a crucial role in the improvement of infrastructure and economy of any country. In many emerging economies, it is apparent that a wide variety of social and political issues are related to the associated supply chain sustainability of financial service firms. Although such sustainability and its implementation issues have largely been addressed in existing research literature and in practice for many years, the attention towards socio-political sustainability aspects has been quite limited. Thus, this study attempted to explore the determinants for improving socio-political sustainability in financial service firms. Through adopting the fuzzy Delphi method (FDM), performing an exhaustive literature review, and conducting semi-structured interviews with the decision-makers of the service firms, nine key barriers for socio-political sustainability were first identified in this study. Then, the influence relationships of the key barriers were assessed by 15 experts. During the assessment process, the interrelationships and their dependence powers among key barriers were analyzed using the interpretive structural modelling (ISM) approach and cross-impact matrix multiplication applied to classification (MICMAC) methods. The assessment results show that among the studied barriers, "antisocial considerations", "unstable political climate", and "lack of political coherence" are the decisive barriers that affect the socio-political sustainability in the supply chain of financial service firms. The knowledge in understanding and reducing these decisive barriers can provide service sector practitioners, especially those with limited resources, the enhanced capability to conduct better planning and designing of effective and continuous improvement programs, so as to win over new consumers and retain existing clients by offering sustainable services.
\end{abstract}

Keywords: supply chain management (SCM); socio-political sustainability; socio-political sustainability barriers; financial service firms; interpretive structural modelling (ISM)

\section{Introduction}

The banking sector has been an integral part of the Indian society since the sector was used as a platform for reducing national poverty and improving society a few decades ago [1]. Nowadays, there is a more urgent need for conducting economic reforms and pursuing intensified competition, as witnessed by the introduction of innovative financial services, as well as the rapid growth in client's needs and expectations for high-quality services [2,3]. Thus, the Reserve Bank of India (RBI) has issued a series of policy measures in recent years to promote the Indian banking sector through its different schemes. The success of those promotional actives has not been quite prominent, but the banks have managed to seek greater visibility in recent five years plans. Moreover, the financial service providers are now facing enormous competition and are under great pressure to 
respond to customers' expectations better and to gain a greater advantage [4,5]. According to recent research studied [6,7], there is a higher demand for improving the suppliercustomer relationship and service quality, and transparency policies, and greater focus on service delivery procedures and cost of services. Indeed, multiple recent sustainability studies have argued that there are different definitions of socio-political sustainability in literature $[8,9]$. In this study, the term "socio-political sustainability" is defined as the development that confirms today's demand without analyzing the responsibility to sustain the next generation [10], and that social, political and society aspects of interrelationships are crucial aspects to be considered for ensuring the overall sustainability.

The prevalent customer-centric management philosophy implies that the entire supply chain needs to be all-encompassing while pursuing the ultimate goal of customer satisfaction $[2,11]$. To achieve this goal, eventually financial service companies need to implement sustainability measures throughout their supply chain, so as to achieve competitive advantage and improve high customer satisfaction [12]. In addition, the most popular topics among analysts and supply chain managers have been social sustainability [13], political issues [14], and environmental sustainability [15] due to the instability of government regulations and increasing expectations among customers in the banking sector. Moreover, modern consumers are concerned not only about their experience with the financial services and features, but also with the service providers' processes and conditions of operation, i.e., how and what quality that the banks can provide [16]. This expectation can increase the pressure on financial service providers to quickly implement sustainable measures. In addition, the rapid development of the banking sector in developing economies necessitates a concurrent improvement in the supply chain activities [17]. Unfortunately, the increase in such activities may result in implications related to social and political issues such as poor living conditions, inequality, child labor, growing gap between the rich and the poor, gender discrimination, political stability, policymaking, and illiteracy that are associated with the supply chain sustainability of financial sector [18,19]. In particular, sustainable social and political practices in the banking firms' supply chain are often absent. Therefore, it remains a great challenge for financial service providers to understand how various social actors interpret sustainability services and integrate them into their individual behavior in order to reach collective social, economic and political decisions [20,21]. Moreover, the banking sector is also facing a few barriers regarding society needs with relevance to public economical safety. As the banking sector is often associated and aligned with government interests and objectives, these barriers and the uncertainty they bring can pose serious challenges to the financial service providers.

In the present literature, there have been several studies on socio-political sustainability related to the supply chain that has been performed so far in developed economies [22,23]. Rock et al. [24] and Golicic et al. [25] have also concluded that the lack of awareness of sociopolitical barriers in many economies may be due to the fact that sustainability in supply chain is often overlooked in emerging economies. In addition, the socio-political sustainability activities often incorporate social, political, and supply chain management methods in order to preserve sustainability in the supply chain and to enhance the socio-political sustainability in the banking sector [26]. Golicic et al. [25] have studied the socio-political sustainability issues in supply chain management and how social problems are concerned within the supply chain. The socio-political sustainability issues often received less attention in the supply chain research then other dimensions of sustainability [27]. And, the social and political issues tend to differ for each economy [28]. Similarly, the impediments and perspective to the implementation of socio-political sustainability would also vary [29]. In addition, very few studies have conducted on the socio-political sustainability barriers in the present literature. For example, Mani et al. [30] and Yadav and Pathak [31] have dealt with systemic approaches focusing mainly on social and environmental sustainability in the supply chain, but they did not focus on socio-political sustainability issues. In addition, Katiyar and Badola [32] focused on barriers to adoption of online banking services; while Behl and Venkatesh analyzed the banking service adoption barriers with the focus on rural 
areas in India [33]. Moreover, those researchers have not focused on the socio-political sustainability and the banking sector to the extent desired [34,35]. In addition, the social and political issues are often unique to every society and highly contextual in nature since social and political systems are usually developed over a long time frame [36]. The supply chain managers of the banking sector in emerging economies are facing three issues. First, they do not have clear information and are not aware of the key obstacles that may impact their socio-political sustainability. Second, they have no knowledge on extent these barriers may lead to unsustainability and on the interrelationship among them. Third, they do not know how to control and eliminate the barriers effectively with limited resources. Moreover, socio-political sustainability issues often receive less attention in supply chain research than the other dimensions of sustainability, and many studies instead focus on the economic and environmental dimensions of sustainability, especially in emerging countries [37-41].

After conducting literature review on studies related to the socio-political sustainability issues for supply chain of banking sector and summarizing the findings, at least two research gaps are observed. First, relatively few studies have conducted systematic analyses of the internal conditions for supply chain of banking sector, as related to the development of the socio-political sustainability at the micro-level. Second, in the few studies that have identified the barriers as influencing their socio-political sustainability, the identified barriers were considered as isolated from each other, without discussing what and how these barriers could influence each other. With this kind of knowledge, the financial service providers will be able to develop more effective controlling measure focusing on decisive factors. Hence the objectives of the current study are framed as follow:

- To determine the key barriers for socio-political sustainability in the supply chain of financial service firms

- To use ISM to establish the hierarchical structural model of the key barriers

- To classify the barriers on the basis of MICMAC results and to determine the most influencing barriers.

Therefore, the current study has focused on the significance of identifying the barriers with regard to the implementation of socio-political sustainability in the supply chain of the financial service firms by performing a two-phase literature review. Then the fuzzy Delphi method (FDM) was used to reach a consensus for barrier selection with the decision-makers of the Indian banking sector to finalize the key barriers [42]. Further, modelling of these key barriers would help to understand the specific interrelation among them. Obtaining the causal relationship between the established constructs would help to know the significance of the association among all the key barriers, through the interpretive structural modelling (ISM) approach [43]. In fact, the ISM approach is an interactive learning tool that can be used to identify the direct and transitive relationships among factors in a particular problem. Though ISM is primarily considered as a group learning method, it can also be used alone, and has been extensively applied to discover barriers and to analyze enablers in various fields $[32,33]$. Finally, the matrix cross-reference multiplication applied to a classification (MICMAC) analysis was employed to help with clustering the barriers that would help to derive the driving power and dependence.

The results of this study identified and clarified that "antisocial considerations" and "unstable political climate" are the most affecting barriers to sustainable operations in the banking supply chain, while "difficulty of implementing CSR (corporate social responsibility)", and "lack of government regulations" are the linkage barriers. In addition, "unemployment", "class-system", "lack of infrastructure conditions" and "lack of a regulatory framework for the service sector" are considered as barriers indirectly affecting supply chain sustainability. Based on the study results, the current study can make contribution in the following two aspects: first, to determine and help to identify the key barriers that may cause non-adoption of socio-political sustainability measures; and second, to help build theory to the literature on the socio-political sustainability in the supply chain of the banking sector relevant to the emerging economies. Such information would help government policymakers and financial service providers to focus on controlling and eliminating the 
key barriers, and would provide clear guidelines to implement the socio-political sustainability in the supply chain of financial service firms in emerging economies, especially in India. Furthermore, the developed hierarchical structural model would be helpful to the government, policymakers, banks, and stakeholders in preparing a sustainable strategy to adopt the socio-political sustainability in supply chain with limited resources for achieving higher customer satisfaction.

Following this Introduction section, the remainder of this article is organized as follows. The next section summarizes the literature review on socio-political sustainability in the banking sector. The findings through the review of the literature lead to the identification of socio-political barriers. In Section 3, the methodology adopted for the current study is outlined. For Section 4 , the discussion of results including managerial implications is presented. Finally, in Section 5, the conclusion and limitations of this study are discussed.

\section{Review of Literature}

\subsection{Evolvement of Socio-Political Sustainability}

Many researchers, when considering the concept of socio-political sustainability, mainly discussed the definition of available sustainable development [44] regarding the aspects of sustainable growth, which satisfy the needs and desires of common societies and are deemed the primary objective in sustaining growth. The primary needs of the majority of humans in developing societies are food, clothing and shelter [45]. Meanwhile, these basic needs are often not being adequately met in many emerging economies. A world with widespread poverty and social injustice is prone to ecological and/or sociological crisis [46]. Therefore, sustainable development ensures the primary needs of societies in emerging economies are met [47]. Literature shows that even the practices of sustainability in the developed economies are not able to completely address the serious issues related to inequality, poor health and insufficient housing $[30,48]$. Meeting the basic human needs in developing countries is a crucial component of the objective of wider sustainability [49]. In the same way, Benatar [50] has argued the importance of eradication of poverty as poverty may lead to social and political devastation.

The Organization for Economic Cooperation and Development (OECD) has defined two main dimensions for analyzing socio-political sustainability: societal and political. On the one hand, the social dimension refers to the poor living conditions, inequality, child labor, growing gap between the rich and the poor, and gender discrimination which define an individual's contribution to the nation's economic development [51] (OECD Report 2018). The political dimension, on the other hand, refers to the political stability and policymaking for society $[52,53]$. There are limited studies on the socio-political sustainability $[54,55]$ aspects. The latest study by Dasgupta [56] has suggested that whatever is common to all and is given free access to humans, would be ruined by human as well. Mutual influence is considered as a means of controlling natural resources. Another study on socio-political sustainability has been helpful in finding such facets of socio-political sustainability and linking them with sustainable development $[35,57]$. These studies have found a number of essential factors on socio-political sustainability, which include access to goods and services, policymaking for sustainable services, and social homogeneity. Perez-Foguet et al. [58] have also found the value of social sustainability which implies the needs to control extremely imposed change with continuing development, human rights, democracy, and competitive strategies that focus on political sustainability.

Garcia et al. [59] have provided empirical results on the social sustainability barriers, but neglected the political point of barriers, and emphasized the necessity for socio-political sustainability on the part of financial service providers. They have placed emphasis the suppliers of the banks by increasing the social capital and political stability of the emerging economies with the human resources of individuals, and adding sustainable value to their services. In another study, Mani et al. [60] discussed the issues related to distribution of power, resources, freedom, and basic infrastructure for sustainable services and access to strategic decision making. Kagawa [61] declared that sustainable development is also 
in favor of the need for equity. Moreover, social equity and political stability are the important pillars for achieving socio-political sustainability in the supply chain, and all the supply chain members have proper rights to utilize the resources, which also extend to the fair treatment of customers. There are a few more studies focusing on socio-political sustainability, and assessing how it influences social well-being and policymaking as in the case of service firms [62]. However, in order to provide more insight on the socio-political sustainability in the supply chain in the rapidly evolving world, the current research has focused on the issues particularly related to the socio-political sustainability in the supply chain of financial service firms.

\subsection{Socio-Political Sustainability in Supply Chain of Banks}

The social and political dimensions are important for the overall sustainability of the bank's supply chain [63]. The arguable question is how the financial service firms can control these social and policy-making issues in their supply chains, while achieving long-term socio-political sustainability. Furthermore, the corporate-oriented concepts of socio-political sustainability may be achieved through socially responsibly acquired resources and provision of equal services to the customers [64,65]. Several studies have analyzed the achievement of sustainability through risk management and gain of overall sustainability in the banks' supply chains [66,67]. Chandra Das [68] concluded that socially responsible policymaking is the essential step to achieve socio-political sustainability in the supply chain management of banks; while another aspect of socio-political sustainability also emphasized is how the financial service providers are more involved in resolving the issues of the supply chain participants than that of the broader society [69]. Moreover, the non-economic aspects of sustainability also affect the supply chain members' trust in each other. For example, the concept of fair trade implies that the trading partners seek to have an equal market value basis, be it a developed economy or a developing economy [70,71] Kedar [72] has differentiated socio-political sustainability, which concentrates on the factors viz. poor living conditions, child labor, inequality, growing gap between the rich and the poor, political stability, illiteracy and policymaking, and all those factors can affect the stability of service quality delivery. Likewise, Vormedal and Ruud [35] and Maes et al. [73] have dealt with different socio-political drivers and their interrelationship related to the sustainability of the supply chain.

However, the current study assumed that there is a scope for more investigation on the other aspects of socio-political sustainability in the supply chain. For example, Koh et al. [74] have highlighted the importance of socio-political sustainability and clarified how it affects the overall sustainability in the supply chain of banks in India.

From a supplier's perspective, $\mathrm{Wu}$ [75] assumed the seriousness of social responsibility at the supplier side, while focusing on the ethical aspects and examined how the buyers can impact sustainability in the supply chain with their behavior, which may in turn impact their operational performance. In the highly competitive market, financial service providers should be aware of flexibility in their operations in providing quality services, in order to meet customers, stakeholders and supplier's expectations for achieving socio-political sustainability in the supply chain [76]. Furthermore, Mathivathanan et al. [77] pointed out that future research on socio-political sustainability should focus on customers' perspective in order to gain a competitive advantage. A recent study also focused on determining social and political issues such as equality, safety, health, and ethics in the supply chain in Indian banks [78]. In other research, different social and political factors are explored to measure the socio-political aspects of the supply chain in developed economies [79], and concluded that there is no consensus on how these socio-political measures are practiced, and what motivated or discouraged the partners from taking socio-political sustainability measures in the supply chain in the emerging economies.

In addition, Xiao [57] analyzed the adoption of socio-political sustainability and that ease and difficulty in achieving associated benefits. Elliott [46] mentioned that banks without socio-political implementation in their organizations may lose customer satisfaction. 
As a result, Behl and Venkatesh [33] analyzed various success factors for sustainability in the banking sector.

From the above review, it is also apparent that there are a few barriers involved throughout the supply chain, which can affect the adoption of socio-political sustainability practices, especially in the emerging economies, and these barriers need to be examined thoroughly. Moreover, socio-political sustainability issues are more complex and can vary from countries to countries, hence the barriers often differ depending on the social and political conditions in developing economies like India.

Through detailed examination of these sustainability issues, the current study is able to fill the gap in this research area by identifying key barriers to socio-political sustainability and their interrelationships in the supply chain of service firms in India. This study can also identify the high driving power barriers and if financial service providers are able to control those barriers, as they will affect the adoption of significant socio-political sustainability.

\section{Methodology}

\subsection{Identification and Determination of Barriers to Socio-Political Sustainability}

The SCM barriers are continue hinder companies from effective achievement of supply chain. According to researchers studied [80], SCM barriers always stay alive between both inside and outside of industrialized organization. For understanding the barriers of SC, completed typical SCM barriers can be found in literatures [80,81]. The previous section has reviewed a wide variety of research studies related to the socio-political sustainability issues and their associated barriers. In order to identify and examine the issues and barriers related to socio-political sustainability in the supply chain, the current study conducted a two-phase comprehensive review of existing literature through searching Scopus, Google Scholar, Science Direct, and Springer databases. The keywords used for the searches included: socio-political sustainability, sustainability barriers, socio-political sustainability barriers, social sustainability, and sustainability in the supply chain. The time frame for the literature survey is 2005-2020, as the vast literature of studies related to socio-political sustainability are covered in two-phases [82].

During the survey, 46 academic papers in phase 1 and 38 papers in phase 2 were found. In all, 84 research papers from several journals related to socio-political sustainability are shortlisted. On the basis of these papers, 12 barriers are noted to be important to socio-political sustainability in the supply chain based on repeated barriers in the select academic papers.

\subsection{Adoption of FDM and ISM Approaches}

\subsubsection{FDM Approach and Results}

Following the identification of potential barriers, the fuzzy Delphi method (FDM) was adopted to confirm the key barriers before the ISM approach was implemented. For this purpose, a questionnaire was issued to collect data from the decision-makers among public and private banks in India. The summary of respondents' is shown in Table 1 . The FDM technique was utilized to confirm the key barriers [42]. The respondents were asked to give a rating on a scale of one to five, i.e., strongly agree, agree, neutral, disagree, and strongly disagree, which corresponds to the scale of 1,2,3,4, and 5 respectively. A total of 40 questionnaires were sent to experts from different service firms and after the screening process, 23 valid samples ( $57.5 \%$ response rate) were taken. During the screening process, the rule to find out if the incomplete or unfilled samples are valid or invalid was adopted. 
Table 1. Profiles of respondents.

\begin{tabular}{ccc}
\hline Demographic Characteristics & \multicolumn{2}{c}{ Classification } \\
\hline Employer & Financial service organization \\
Type of the organisation & Public & Private \\
Number & 8 & 15 \\
Year(s) of experience in the present organisation & \multicolumn{2}{c}{$>$} \\
Year(s) of experience within the sector & $>5$ Years \\
Educational qualification & All have Bachelor degree \\
\hline
\end{tabular}

The FDM is a structured technique of consensus-building based on a group of decisionmakers who provide opinions through a questionnaire survey. Thus, it could be assumed that FDM is a systematic approach to decide through consensus. For valid responses, fuzzy Delphi analysis was made. On the base of threshold value (0.65) for the fuzzy Delphi result, 9 barriers were identified as key socio-political sustainability barriers of the banking supply chain. The finalized key barriers are listed and defined in Table 2.

Table 2. Barriers to socio-political sustainability.

\begin{tabular}{|c|c|c|}
\hline Barriers & Definition of Factors & References \\
\hline $\begin{array}{l}\text { Difficulty of implementing CSR } \\
\text { (corporate social responsibility) (B1) }\end{array}$ & $\begin{array}{l}\text { This factor refers to the no-mutual trust relationship of firms and } \\
\text { governments liaise which impede CSR implementation in banks. }\end{array}$ & {$[83,84]$} \\
\hline Antisocial considerations (B2) & $\begin{array}{l}\text { This factor refers to the non-supportive social responsively of a } \\
\text { bank that will impede the bank to achieve organisational objectives. }\end{array}$ & {$[85,86]$} \\
\hline Unemployment (B3) & $\begin{array}{l}\text { This factor refers to the unemployment fluctuations that affect the } \\
\text { healthiness of the market. }\end{array}$ & [87-91] \\
\hline Class-system (B4) & $\begin{array}{l}\text { The class-system refers to the distinction of the social stratum of } \\
\text { society which discourages the promotion of autonomy and can } \\
\text { ultimately lead to a lack of interest and motivation. }\end{array}$ & [92-94] \\
\hline Unstable political climate (B5) & $\begin{array}{l}\text { The institutional weakness and the lack of cooperation between } \\
\text { banks or banks' stakeholders contributed to the instability. }\end{array}$ & {$[28,95,96]$} \\
\hline Lack of infrastructure considerations (B6) & $\begin{array}{l}\text { This factor refers to the lack of basic infrastructure in rural areas } \\
\text { such as power, roads, skilled workers, and resource availability. }\end{array}$ & [97-99] \\
\hline $\begin{array}{l}\text { Lack of regulatory framework for service } \\
\text { sector (B7) }\end{array}$ & $\begin{array}{l}\text { This factor stands for the ineffective regulatory frame, regulations } \\
\text { inadequate to promote services, lack of a favourable provision for } \\
\text { the banking sector. }\end{array}$ & {$[1,100-103]$} \\
\hline Lack of government regulations (B8) & $\begin{array}{l}\text { Incentives and benefits provided by the government do not support } \\
\text { the adoption of sustainability in the service supply chain. }\end{array}$ & {$[1,95,103-106]$} \\
\hline Lack of political coherence (B9) & $\begin{array}{l}\text { Lack of political coherence refers to how the political leaders } \\
\text { implement the policies for banking sector growth. }\end{array}$ & {$[28,107,108]$} \\
\hline
\end{tabular}

\subsubsection{ISM Approach}

In the current study, the relationships among the barriers for socio-political sustainability in the supply chain were analyzed subsequently following identification of barriers. For this purpose, the finalized key barriers were modelled using the Interpretive Structural Modelling (ISM) technique [109]. The ISM methodology has found its place in the field of social science research, and has been one of the most cited methodologies in recent years. It is a very important technique particularly when there is a lack of supporting literature in terms of the relationship between socio-political barriers in the banking sector. However, the ISM approach does have some limitations, for example, it does not provide an explanation for interpreting the links, and it also lacks complete transparency regarding its methodology [110]. Moreover, to produce an appropriately construct cluster, equal weighting needs to be evaluated by performing an MICMAC analysis [111]. If there is any interruption issue in implementing this methodology while forming an initial or final reachability matrix and drawing an ISM network, further support would need to be sought from decision-makers and literature. The results for the implementation of methodology and relationship model, and the respective results for identified barrier for this study 
are presented in Section 4 below. The research methodology adopted for this study is summarized in Figure 1.

Detailed steps related to the implementation of the ISM approach, including the development of relevant matrixes will be presented together with the modelling results in Section 4.

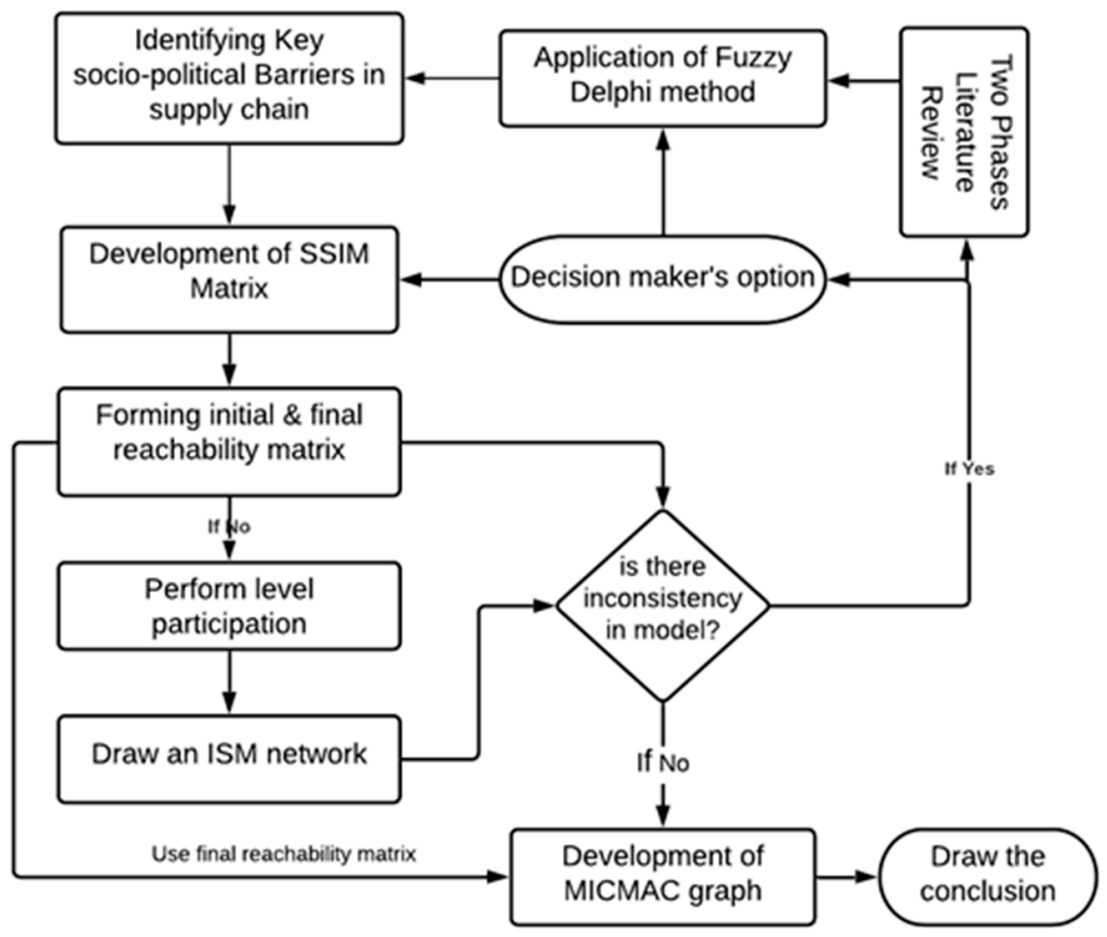

Figure 1. Flow of ISM.

\section{Results and Discussion}

\subsection{Interpretive Structural Modelling}

As described above, the interpretive structural modelling (ISM) approach was adopted to achieve the objective of this study. First introduced in 1970, the ISM is an approach used to describe the relationships among the variables which determine a problem [112]. It is an interactive learning method which helps to improve order and address complex relationships among barriers in a system [113]. As shown in Figure 1, the methodology makes use of decision makers' views to explore the relationships among barriers in the supply chain that can influence socio-political sustainability. The association between any two barriers ( $i$ and $j$ ) and the related routing of the relationship were future examined, after finalizing and establishing the definition of each barrier.

\subsubsection{Structural Self-Interaction Matrix (SSIM)}

For developing the contextual relationship among the concerned barriers, experts' responses were collected again from the decision-makers of financial service firms in India. Thirteen decision-makers from the banking sector and two from academia with a research interest in this area were consulted and their profiles summarized in Table 3 . The majority of experts consulted for this study have more than five years of experience in their respective field. During the development of the structural self-interaction matrix (SSIM), the following four symbols were used to establish the relationship between the barriers in respect of the two barriers (row $i$ and column $j$ ).

$\mathrm{V}$ barrier $i$ influences barrier $j$;

A barrier $i$ is influenced by barrier $j$;

$X$ barrier $i$ and $j$ influence each other; and

$\mathrm{O}$ barrier $i$ and $j$ are unrelated. 
Table 3. Profile of experts.

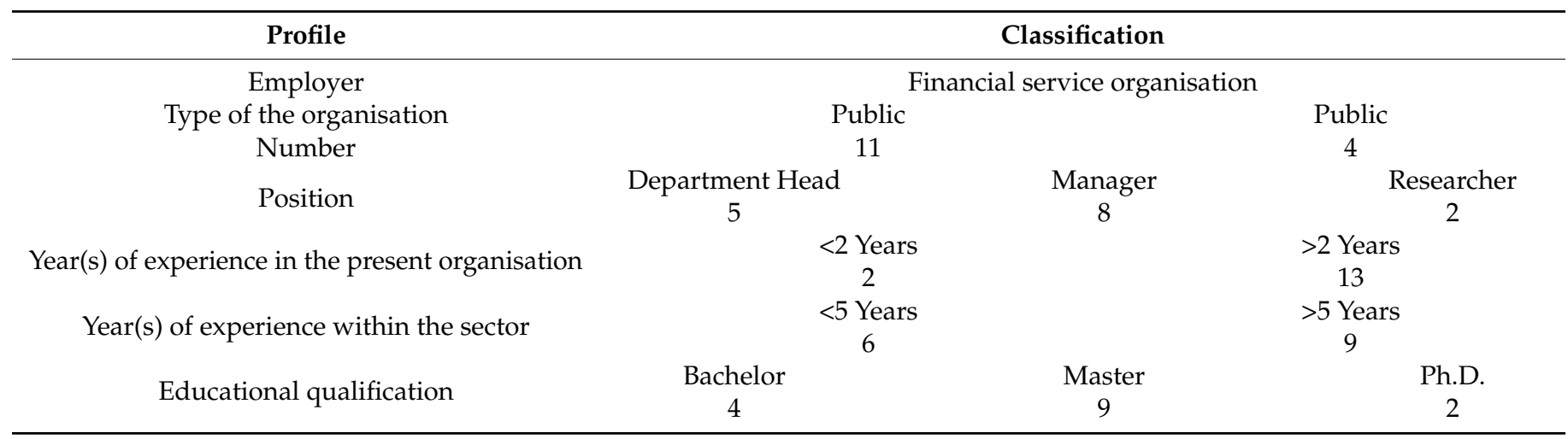

For example, the barrier "antisocial considerations (B2)" influences the barrier "lack of regulatory framework for the service sector (B7)", so symbol $\mathrm{V}$ has been noted in the cell $(3,4)$ while the barrier "unemployment (B3)" is influenced by the barrier "lack of political coherence (B9)", so symbol A has been noted in the cell $(4,2)$. The pairwise comparison of the contextual relationships of the key barriers is shown in Table 4.

Table 4. Structural self-interaction matrix (SSIM) of socio-political sustainability barriers.

\begin{tabular}{cccccccccc}
\hline Barriers & B9 & B8 & B7 & B6 & B5 & B4 & B3 & B2 & B1 \\
\hline B1 & A & X & V & V & A & V & O & A & \\
B2 & V & V & V & V & X & V & V & & \\
B3 & A & A & O & A & A & X & & & \\
B4 & A & A & A & A & A & & & \\
B5 & V & V & V & V & & & & \\
B6 & O & A & A & & & & & \\
B7 & A & A & & & & & & \\
B8 & A & & & & & & & \\
B9 & & & & & & & & \\
\hline
\end{tabular}

\subsubsection{Development of the Initial Matrix and Final Matrix for Reachability}

The symbols $(\mathrm{V}, \mathrm{A}, \mathrm{X}, \mathrm{O})$ in SSIM are transformed into a binary digit (1s or 0s) matrix when the SSIM is obtained, which is called the initial matrix of reachability (IMR) [114-116]. The rules for transferring symbols into binary digits are shown in Table 5.

Table 5. Conversion rule for transferring SSIM into an initial matrix of reachability (IMR).

\begin{tabular}{ccc}
\hline \multirow{2}{*}{$(i, j)$ Values in SSIM } & \multicolumn{3}{c}{ Conversion Value in IRM } \\
\cline { 2 - 3 } & $(i, j)$ & $(j, i)$ \\
\hline V & 1 & 0 \\
X & 0 & 1 \\
O & 1 & 1 \\
\end{tabular}

The IMR can be developed to explain the relationship among the nine barriers as presented in Table 6. Subsequently, the IMR can be converted into the final matrix of reachability (FMR) using the transitivity rule presented by Menon and Suresh [117]. The transitivity rule is used to denote the contextual relation among barriers as follows: If barrier A can influence barrier B, and barrier B also can influence barrier $C$, then barrier $A$ will necessarily influence barrier $C$. Based on this rule, as shown in Table 6, if barrier B1 can influence barrier B6 and barrier B6 also can influence barrier B3, then barrier B1 will influence barrier B3. 
Table 6. IMR of the barriers of socio-political sustainability.

\begin{tabular}{cccccccccc}
\hline \multirow{2}{*}{ Barriers $\mathbf{B}_{\mathbf{i}}$} & \multicolumn{10}{c}{ Barriers $\mathbf{B}_{\mathbf{j}}$} \\
\cline { 2 - 10 } & B1 & B2 & B3 & B4 & B5 & B6 & B7 & B8 & B9 \\
\hline B1 & 1 & 0 & 0 & 1 & 0 & 1 & 1 & 1 & 0 \\
B2 & 1 & 1 & 1 & 1 & 1 & 1 & 1 & 1 & 1 \\
B3 & 0 & 0 & 1 & 1 & 0 & 0 & 0 & 0 & 0 \\
B4 & 0 & 0 & 1 & 1 & 0 & 0 & 0 & 0 & 0 \\
B5 & 1 & 1 & 1 & 1 & 1 & 1 & 1 & 1 & 1 \\
B6 & 0 & 0 & 1 & 1 & 0 & 1 & 0 & 0 & 0 \\
B7 & 0 & 0 & 0 & 1 & 0 & 1 & 1 & 0 & 0 \\
B8 & 1 & 0 & 1 & 1 & 0 & 1 & 1 & 1 & 0 \\
B9 & 1 & 0 & 1 & 1 & 0 & 0 & 1 & 1 & 1 \\
\hline
\end{tabular}

Based on this rule, the FMR has been derived by checking the transitivity among the key barriers as shown in Table 7.

Table 7. FMR of the barriers of socio-political sustainability.

\begin{tabular}{ccccccccccc}
\hline \multirow{2}{*}{ Barriers $\mathbf{B}_{\mathbf{i}}$} & \multicolumn{10}{c}{ Barriers $\mathbf{B}_{\mathbf{j}}$} \\
\cline { 2 - 10 } & B1 & B2 & B3 & B4 & B5 & B6 & B7 & B8 & B9 & Driving Power \\
\hline B1 & 1 & 0 & $1^{*}$ & 1 & 0 & 1 & 1 & 1 & 0 & 6 \\
B2 & 1 & 1 & 1 & 1 & 1 & 1 & 1 & 1 & 1 & 9 \\
B3 & 0 & 0 & 1 & 1 & 0 & 0 & 0 & 0 & 0 & 2 \\
B4 & 0 & 0 & 1 & 1 & 0 & 0 & 0 & 0 & 0 & 2 \\
B5 & 1 & 1 & 1 & 1 & 1 & 1 & 1 & 1 & 1 & 9 \\
B6 & 0 & 0 & 1 & 1 & 0 & 1 & 0 & 0 & 0 & 3 \\
B7 & 0 & 0 & $1^{*}$ & 1 & 0 & 1 & 1 & 0 & 0 & 4 \\
B8 & 1 & 0 & 1 & 1 & 0 & 1 & 1 & 1 & 0 & 6 \\
B9 & 1 & 0 & 1 & 1 & 0 & $1^{*}$ & 1 & 1 & 1 & 7 \\
Dependence & 5 & 2 & 9 & 9 & 2 & 7 & 6 & 5 & 3 & 48 \\
\hline
\end{tabular}

Note: $1^{*}$ represents transitivity relationship.

\subsubsection{Level Partitions}

The level partitioning can be done from the FMR, with the reachability set and antecedent set established for one another [118]. For the reachability set, it is consisted of the barrier itself and the other barriers, which it influences, while the antecedent set is constituted by the barrier itself and the other barriers that can influence it. After the reachability set and the antecedent set are derived, their intersection sets can be derived for all the barriers.

For the barriers with the same reachability and intersection sets, they are assigned as a level 1 barrier set and considered as the first level. After deriving level 1, the involved interactive barriers were ignored for further levels. This iterative process would be continued until the level of each barrier is found. The partition result of the reachability matrix of interactions is presented in Table 8 and Appendix A. Six interactions were found in this study. From the level partition interaction 1 to 6 , the B3 and B4 barriers identified in level 1 and B2 and B5 barriers identified in level 6 were examined. Level 6 factors are the most important socio-political sustainability barriers among all barriers. 
Table 8. Result of level partition iteration.

\begin{tabular}{ccccc}
\hline Barriers & Reachability Set $\mathbf{R}\left(\mathbf{B}_{\mathbf{i}}\right)$ & Antecedent Set A $\left.\mathbf{B}_{\mathbf{j}}\right)$ & Intersection Set $\mathbf{R}=\mathbf{R}\left(\mathbf{B}_{\mathbf{i}}\right) \cap \mathbf{A}\left(\mathbf{B}_{\mathbf{j}}\right)$ & Level \\
\hline B1 & B1, B8 & B1, B2, B5, B8, B9 & B1, B8 & IV \\
B2 & B2, B5 & B2, B5 & B2, B5 & VI \\
B3 & B3, B4 & B1, B2, B3, B4, B5, B6, B7, & B3, B4 & I \\
B4 & B8, B9 & B3, B4 & I \\
B5 & B3, B4 & B1, B2, B3, B4, B5, B6, B7, & B2, B5 & BI \\
B6 & B2, B5 & B8, B9 & B6 & II \\
B7 & B6 & B2, B5 & B7, B9 & III \\
B8 & B7, B9 & B1, B2, B5, B7, B8, B9 & B1, B8 & IV \\
B9 & B1, B8 & B1, B2, B5, B8, B9 & B9 & V \\
\hline
\end{tabular}

\subsection{Development and Results of ISM Structural Model}

The final ISM-based model for barriers affecting the socio-political sustainability of the banking sector in India can be constructed from both the level partition result shown in Table 8 and the final reachability matrix shown in Table 7. Based on the result of level partition, a directed diagram including nodes and transitivity links can be generated. In this diagram, arrows between nodes are used to show the direction of the influence. Therefore, if barrier $i$ influences $j$, an arrow will point from $i$ to $j$. For example, the barrier "unstable political climate (B5)" will influence the barrier "lack of political coherence (B9)", so an arrow is shown to point from B5 to B9. Through this method, the top-level barriers are placed at the top of the diagram and the lower levels are placed at lower positions of the diagram. Finally, the diagram is completed by removing the indirect links, as depicted in Figure 2.

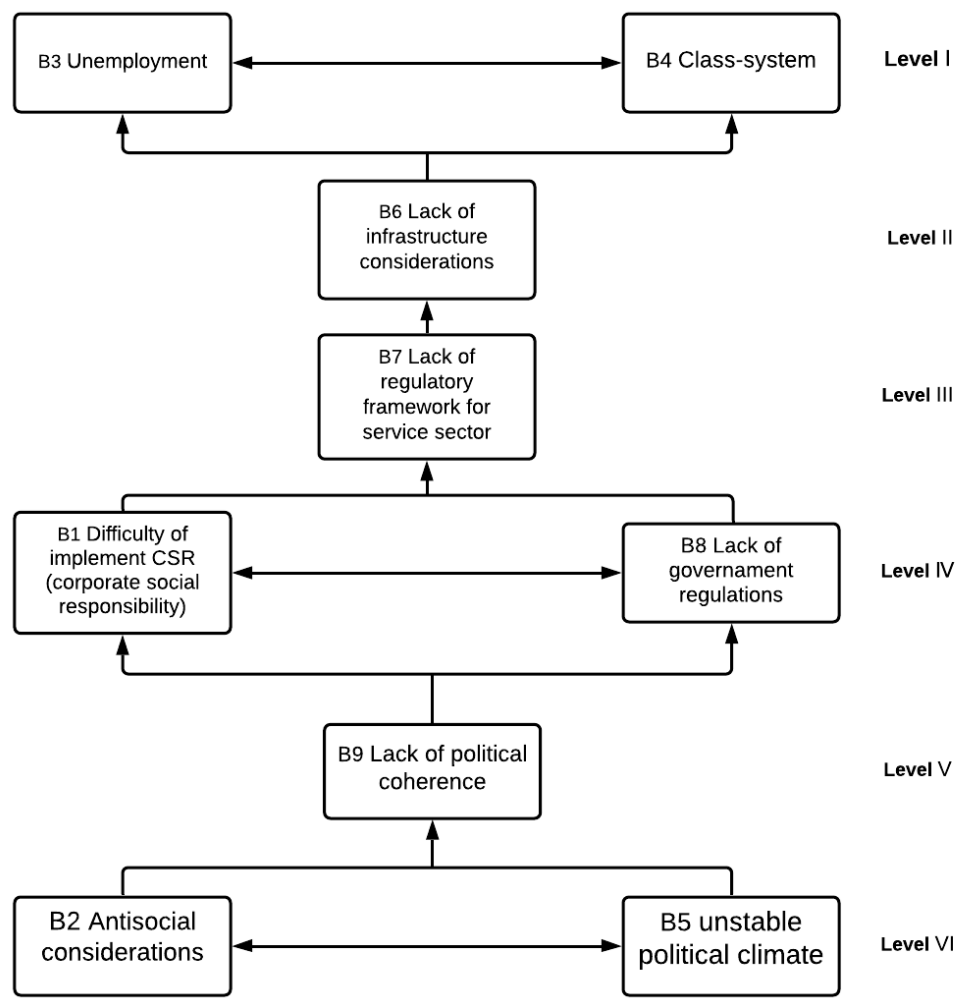

Figure 2. ISM hieratical network of the barriers of socio-political sustainability in the banking sector. 


\subsection{Results of MICMAC Analysis}

In this study, the MICMAC analysis is used to analyze the key barriers' driving power and dependence [119] through ranking the barriers based on their driving power divided by dependence [120] as shown in Table 9. Through this approach, the socio-political barriers are classified into four zones, namely autonomous barriers, dependent barriers, linkage barriers, and independent barriers, as given in Figure 3.

Zone I: Autonomous barriers are those with low driving power and dependence [121], and they are relatively disconnected from the system. In this study, there are no autonomous barriers.

Zone II: Dependent barriers tend to have weaker driving power but stronger dependence $[122,123]$. In this study, the barriers B3, B4, B6, and B7 are the dependent barriers.

Zone III: Linkage barriers are those that may have stronger driving power and dependence $[124,125]$. These barriers are unique in that any action on these barriers that may affect others could also have a feedback effect on them. In this study, the barriers B1 and $\mathrm{B} 8$ are the linkage barriers.

Zone IV: Independent barriers or triggering barriers are those with stronger driving power but weaker dependence [126]. These barriers tend to be the most important ones, so that the utmost priority of a firm's policymaker may be to gain control of these barriers. In this study, the barriers B2, B5, and B9 are the independent barriers.

Table 9. Driving power and dependence computation of cross-impact matrix multiplication applied to classification (MICMAC) ranks.

\begin{tabular}{ccccc}
\hline Barriers & Driving Power & Dependence & Driving Power/Dependence & MICMAC Rank \\
\hline B1 & 6 & 5 & 1.2 & 3 \\
B2 & 9 & 2 & 4.5 & 1 \\
B3 & 2 & 9 & 0.222222222 & 6 \\
B4 & 2 & 9 & 0.222222222 & 6 \\
B5 & 9 & 2 & 4.5 & 1 \\
B6 & 3 & 7 & 0.428571429 & 5 \\
B7 & 4 & 6 & 0.666666667 & 4 \\
B8 & 6 & 5 & 1.2 & 3 \\
B9 & 7 & 3 & 2.333333333 & 2 \\
\hline
\end{tabular}

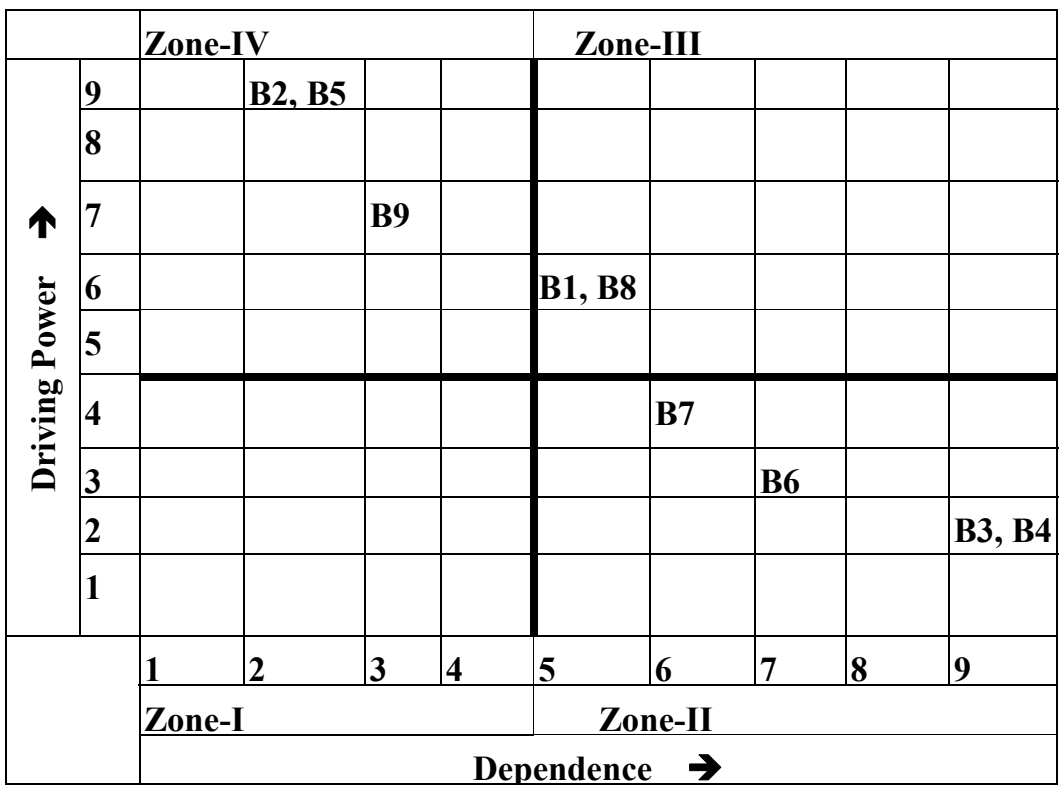

Figure 3. Result of MICMAC analysis of the barriers. 


\subsection{Discussion of Results}

\subsubsection{ISM Analysis}

In this study, the ISM analysis was implemented to obtain the hierarchy model used for understanding the interrelationships among the key barriers for implementing sociopolitical sustainability in the supply chain of banks. The results of the current study should be able to offer significant insights into the socio-political sustainability barriers for the implementation of measures in achieving socio-political sustainability in their supply chain. For the hierarchy of key barriers, banking sector experts largely agreed that changing the political environment and competition between government and private banks may affect the industry's growth or even reduce clients' trust in the banking system. Therefore, "antisocial considerations" along with "unstable political climate" appeared as important barriers at the bottom of the hierarchy. They also mentioned that lack of policy development and implementation by the government is causing "difficulty of implementing CSR (corporate social responsibility)", "lack of government regulations", and "lack of regularity framework for the service sector" to emerge as the linking barriers. Moreover, whether the banking sector is losing or gaining growth is greatly affected by the society at large, and this consideration is causing the "unemployment" and "class system" to emerge as the barriers at the top strategic level.

Furthermore, the findings suggested that the key barriers to the implementation of socio-political sustainability in supply chains are of utmost importance, because if addressed adequately, these barriers could generate a chain reaction with other barriers and improve the visibility of the socio-political sustainability in the supply chain. As of now, when compared with other sustainability aspects associated with the supply chain, the literature on the studies of socio-political sustainability issues continues to be evolving. The outcome of the ISM model in this study would not only enable the supply chain managers and policymakers to better formulate their social responsibility and understand the political issues but also provide first-hand information on the key barriers so that they can be addressed effectively. In addition, this study has identified nine barriers relevant to socio-political sustainability and subsequently prioritized their importance in accordance with their respective level in the hierarchy model. The result of the ISM model network is significant as it reveals a six-level hierarchy of barriers as shown in Figure 2. As per the ISM network, the "antisocial considerations (B2)" barrier and "unstable political climate (B5)" barrier come out as the strongest barriers with high driving power at the sixth level. These results are consistent with the study conducted by Chandra Das [68]. He has pointed out that the social responsibility and policymaking process are the essential steps to achieving socio-political sustainability in the supply chain management of banks. Kagawa [61] also declared that social equity and political stability are the important pillars for achieving the socio-political sustainability in the supply chain. Therefore, banks in India must focus on setting up effective strategies to control high driving power barriers. Likewise, the "lack of political coherence (B9)" barrier is the most significant barrier at level five, while "unemployment (B3)", "class-system (B4)", and "lack of infrastructure conditions (B6)" barriers are of low driving power. These barriers are dependent barriers, and the linking barriers are automatically controlled if financial service firm's managers effectively control the high driving barriers, whereas low driving power barriers do not affect the socio-political sustainability much in the supply chain. In contrast, barriers including "difficulty of implementing CSR (corporate social responsibility) (B1)", "lack of government regulations (B8)", and "lack of regularity framework for the service sector (B7)" are in the middle of the hierarchy in the ISM model network in this study. Therefore, this level of barriers is unstable. This information would help the practitioners in preparing effective strategies to implement socio-political sustainability in the bank's supply chain. In addition, Rehman et al. [127] have reminded that consistency in strategy development will still be needed for long-term survival and sustainability. 


\subsubsection{Results of MICMAC Analysis}

Based on the MICMAC analysis, the key barriers of socio-political sustainability can be divided into four zones, i.e., autonomous zone, dependent zone, linkage zone, and independent zone. The MICMAC analysis of barriers is depicted in Figure 3.

Autonomous zone: In this zone, none of the barriers is found to have socio-political sustainability implications in the supply chain. Although the absence of such barriers in this study prevented them from holding a significant role, if present, these barriers tend to have weaker driving power and dependence. Usually, the barriers falling within this zone are not very important and have less impact upon other barriers in leading to implications for socio-political sustainability in the supply chain.

Dependent zone: In this zone, barriers tend to have weaker driving power but stronger dependence among them. It includes four barriers that have been identified to be "unemployment (B3)", "class system (B4)", "lack of infrastructure conditions (B6)", and "lack of regulatory framework for the service sector (B7)", which is based on the results of MICMAC analysis, as mentioned in Figure 3. These barriers may have a limited effect on socio-political sustainability in the supply chain. In addition, to better control these barriers, the management needs to consider the barriers' dependence at a low level, as all other barriers can strongly influence the low-level barriers. Moreover, the barriers at the middle level can also strongly influence the low-level barriers.

Linkage zone: The barriers in this zone have both high driving power and dependence. These barriers are usually not stable due to the inherent variability and the causal loop among themselves. As per the results of the MICMAC analysis shown in Figure 3, the barriers of "difficulty in implementing CSR (corporate social responsibility) (B1)" and "lack of government regulations (B8)" are deemed the linkage barriers falling within this zone, which are highly unstable. The aforementioned middle-level barriers usually require continuous observation for their influence on the barriers at the top level.

Independent zone: In this zone, barriers tend to have stronger driving power but weaker dependence. Three barriers are identified for this zone, namely "antisocial considerations (B2)", "unstable political climate (B5)", and "lack of political coherence (B9)". These barriers are placed at the bottom level of the ISM hierarchy model, and they are key barriers of the MICMAC analysis. The barriers with very strong driving power in the independent zone are called very important or key barriers, since they often have strong influence on the other barriers in the linkage and dependent cluster. These barriers are generally regarded by the decision-makers as the focus of their respective management strategy, and the management usually place high priority on overcoming these barriers. The lower level barriers are primarily responsible for leading the barriers to the creating significant impact on the barriers at the top level. These barriers, namely "antisocial considerations (B2)", "unstable political climate (B5)", and "lack of political coherence (B9)" can affect the other barriers and increase the complexity of influence on the implementation of the socio-political sustainability within the supply chain of banks. Therefore, financial service firms would need to focus more effectively on addressing this zone of barriers.

\subsubsection{Managerial Implications}

The findings of this study can also have significant managerial implications for the banking sector practitioners in developing better plans and making use of their limited resources to design effective improvement programs for controlling and eliminating the barriers, as well as enhancing performance, attracting new consumers and retaining current clients through offering sustainable financial services. Based on the findings of this study, the relevant implications are discussed as follows.

First, attention should be paid to barriers with social considerations. The ISM hierarchical model (Figure 2) and MICMAC analysis (Figure 3) have both shown that the barriers "antisocial considerations (B2)" and "unstable political climate (B5)" are the decisive barriers for achieving socio-political sustainability in the banking sector, as they have high driving power and are located at the bottom part of the diagram from the ISM 
hierarchical model and Zone IV in the MICMAC analysis. Therefore, bank managers and policymakers ought to monitor and evaluate high driving power barriers, such as antisocial considerations (B2), as they refer to a bank's non-supportive social responsibility that can prevent the bank from achieving organizational objectives. According to Yüksel [87], social development activities (e.g., community involvement program, sponsoring, and charity) and internal socio-ethical activities (e.g., anti-corruption policy and procedure, corporate ethics/values, labor standards, human rights, and gender equality and diversity) are the attributes of supportive social responsibility. In addition, with the FinTech application's popularity and implementation, new social concerns, such as increased dependency on non-humans, safety, trust, job security, and lack of information [128] are also taken into account in social responsibility.

Second, attention should be paid to further enhancement of political climate consensus. As per the majority of experts' options, the "unstable political climate" barrier is also one of the key socio-political barriers, as shown in Figure 2. The "unstable political climate (B5)" barrier can affect the government's policy-making stability and may lead to reducing the investor's decisions as well as the customer's confidence or trust. A strong and efficient institution is defined as the one with the consistency in policy goals, instruments, and other policy-related signals. It is an important element that can make the political climate stable and can systematically reduce conflicts and promote synergies between and within different policy areas to achieve the outcomes associated with jointly agreed policy objectives. The design of a strong and efficient institution requires acknowledging the corresponding system's feedback structure. Therefore, the banking sector policymakers need to strategize and review the existing political environment and take quick action against the barriers in existing political climate.

Third, attention should be paid to conduct monitoring of political coherence. Another observation from the ISM hierarchical model (Figure 2) and MICMAC analysis (Figure 3) is that the barriers "antisocial considerations (B2)" and "unstable political climate (B5)" may lead to other barriers such as "lack of political coherence (B9)". Lo [129] suggested that the political environment may change due to political coherence in the less developed and developing countries. Moreover, the banking sector is often operating very close to government objectives and is reflective of the respective country's economy. Therefore, the public sector bank's senior managers, policymakers, and clients must focus on political parties' actions in their regions in order to overcome the impact of political coherence. In turn, this barrier may lead to level 4 barriers such as "difficulty of implementing CSR (corporate social responsibility) (B1)" and "lack of government regulations (B8)". A recent study by Chlela [80] concluded that corporate social responsibility may be the most effective barrier. To overcome this barrier, the governments should motivate the public and private banks to participate in socially reasonable activities. To overcome the barrier "lack of government regulations (B8)", the government must focus on providing benefits to the banking sector in developing countries, such as on different types of liberalization policy support from governmental bodies, providing infrastructure, improving interconnection standards, and speeding up licensing procedures. Furthermore, this barrier may lead to the "lack of a regularity framework for the service sector (B7)" barrier and influence the "lack of infrastructure conditions (B6)" barrier. In addition, this barrier can also lead to improvement in "unemployment (B3)" and "class-system (B4)" barriers. The bank's top-level management should also eliminate the high driving power barriers, which automatically control high dependence barriers. If implemented properly, these developments may be able to facilitate the achievement of overall sustainability of financial intuitions in developing countries.

Currently, the Indian banking sector is not treating the socio-political sustainability as a priority for the banks and its supply chains. The banks are suffering from a lack of proper guidelines at the organization level and from the government authorities for the successful implementation of socio-political sustainability throughout the financial service's supply chain. To overcome this problem, it is necessary to take certain actions towards improving the sector's sustainability strategy. At the government's administrative level, there is a 
strong need to provide a single-window clearance policy for banks. For the successful implementation of socio-political sustainability in their supply chain, it is necessary to be aware of the societal and political problems among all the supply chain members. It is also necessary to have a systematic grassroots-level assessment and understanding related to implementing socio-political sustainability within the supply chain. There is also a need to provide proper information regarding the current social and political issues to their supply chain members as well as customers by the financial service providers. The provision of such information may improve the trust among the whole supply chain members and customers as well as lead towards achieving high customer satisfaction. Furthermore, the result of this research can support sustainable development for the banking sector and create new opportunities for future growth through avoiding these barriers. The renewed efforts on sustainable development for the banks with the aspirations of addressing sociopolitical sustainability issues may also help researchers to again focus on closing the gap for this issue in both theory and practice.

\section{Conclusions}

It is important to realize that in the future, there will be greater competition between entities within the supply chains, rather than those within the financial service providers [130]. Therefore, the current study can contribute to the existing empirical literature on sociopolitical sustainability through offering a systematic analysis of the key barriers related to the supply chain of banks. This study has endeavored to explore these barriers from a social and political point of view, and it has provided valuable contributions to the socio-political sustainability and supply chain literature from the theoretical perspective. The result of this study identified the most significant barriers within the supply chains for socio-political sustainability such as "antisocial considerations (B2)" and "unstable political climate (B5)". If these barriers are effectively monitored and eliminated, socio-political sustainability may become a reality in the financial service sector's supply chain in the emerging economies. The financial service providers also need to find ways and means to reconfigure their sustainable supply chain strategies in order to integrate socio-political sustainability into their supply chain, which would allow for the differentiation from their current and potential competitors. A serious problem for addressing the socio-political sustainability issues in both micro and macro levels is the pressure imposed on the financial service providers to adopt future strategies and measures to improve the socio-political sustainability of their supply chains. To be able to compete globally, the banks must address the pressure coming from the political system and society, and they must strive to incorporate sustainable measures in their supply chains. From this perspective, this study is even more relevant, as it focused on exploring the key socio-political sustainability barriers and their contextual interrelations to improve sustainability in the supply chain.

This study has also identified and examined the key barriers and established the model-based barriers to socio-political sustainability, which are generated from research gaps among the existing socio-political sustainability and supply chain literature. Hence, this research may be helpful to the current service firms in developing a long-term sustainable strategy and providing quality services to their customers. The ISM and MICMAC techniques adopted for this study could describe the structural relationships among the key barriers and highlight the boundaries, and they would help financial service providers and SCM experts in making better use of the organization's resources in their decision-making process. Based on ISM and MICMAC analysis, the banks would need to prevent the high driving power barriers in order to achieve sustainable customer satisfaction. However, this does not mean they have to ignore the low driving power barriers. This research also aimed to examine these socio-political sustainability barriers and has endeavored to find a new way to incorporate them into the present banks that contribute to the economic growth of the country, especially in emerging economies. In the future, results from this study may help to enhance the quality of service, reduce the consumption of resources, 
and optimize the efforts of existing service firms that face challenges in achieving high customer satisfaction and sustainability issues in their economies.

Finally, the current research and associated results do have a few limitations. First, this research mainly focusses on the socio-political sustainable barriers in the supply chain of the banking sector in developing economies, particularly India; however, social and political issues can vary greatly among different economies, be it developed or developing economies. In the present literature, the disadvantages of not achieving socio-political sustainability are not limited to any sector in particular. Future research may extend this type of study to several other sectors using multiple methods, such as TISM or fuzzy ISM. Recently, a few researchers have noted the limitations of using the ISM [131] approach in similar studies.

Second, the results of this study have not been statistically verified, as it was conducted with the constraints such as limited resources, so the ISM developed was based on the subjective judgment of select decision-makers from the Indian banking sector. It is suggested that future research should be empirically verified by using statistical technique such as structural equation modelling (SEM).

Despite the above limitations, and while this study focused mainly on the banking sector of India, it is expected that the knowledge and perspectives gained from the Indian experience through this study should be of value in addressing similar issues in other developing economies.

Author Contributions: Conceptualization: W.-K.C. and V.N.; Methodology: W.-K.C. and C.-T.L.; Data curation: W.-K.C. and V.N.; Data collection: M.-L.L.; Data analysis: W.-K.C., V.N. and M.-L.L.; Writing-original draft preparation: W.-K.C. and V.N.; Review and editing: W.-K.C., V.N., M.-L.L. and C.-T.L.; Validation: M.-L.L. and C.-T.L. All authors have read and agreed to the published version of the manuscript.

Funding: This research was funded by the Ministry of Science and Technology of Taiwan grant number MOST 108-2221-E-212-001-MY2.

Institutional Review Board Statement: Not applicable.

Informed Consent Statement: Informed consent was obtained from all subjects involved in the study.

Data Availability Statement: Not applicable.

Conflicts of Interest: The authors declare no conflict of interest.

\section{Appendix A}

Table A1. Level partition iteration I.

\begin{tabular}{cccc}
\hline Barriers & Reachability Set $\mathbf{R}\left(\mathbf{B}_{\mathbf{i}}\right)$ & Antecedent Set A (B) & Intersection Set $\mathbf{R}\left(\mathbf{B}_{\mathbf{i}}\right) \cap \mathbf{A}\left(\mathbf{B}_{\mathbf{i}}\right)$ \\
\hline B1 & $\mathrm{B} 1, \mathrm{~B} 3, \mathrm{~B} 4, \mathrm{~B} 6, \mathrm{~B} 7, \mathrm{~B} 8$ & $\mathrm{~B} 1, \mathrm{~B} 2, \mathrm{~B} 5, \mathrm{~B} 8, \mathrm{~B} 9$ & \\
$\mathrm{~B} 2$ & $\mathrm{~B} 1, \mathrm{~B} 2, \mathrm{~B} 3, \mathrm{~B} 4, \mathrm{~B} 5, \mathrm{~B} 6, \mathrm{~B} 7, \mathrm{~B} 8, \mathrm{~B} 9$ & $\mathrm{~B} 2, \mathrm{~B} 5$ & $\mathrm{~B} 3, \mathrm{~B} 4$ \\
$\mathrm{~B} 3$ & $\mathrm{~B} 3, \mathrm{~B} 4$ & $\mathrm{~B} 1, \mathrm{~B} 2, \mathrm{~B} 3, \mathrm{~B} 4, \mathrm{~B} 5, \mathrm{~B} 6, \mathrm{~B} 7, \mathrm{~B} 8, \mathrm{~B} 9$ & $\mathrm{~B} 3, \mathrm{~B} 4$ \\
$\mathrm{~B} 4$ & $\mathrm{~B} 3, \mathrm{~B} 4$ & $\mathrm{~B} 1, \mathrm{~B} 2, \mathrm{~B} 3, \mathrm{~B} 4, \mathrm{~B} 5, \mathrm{~B} 6, \mathrm{~B} 7, \mathrm{~B} 8, \mathrm{~B} 9$ & $\mathrm{I}$ \\
$\mathrm{B} 5$ & $\mathrm{~B} 1, \mathrm{~B} 2, \mathrm{~B} 3, \mathrm{~B} 4, \mathrm{~B} 5, \mathrm{~B} 6, \mathrm{~B} 7, \mathrm{~B} 8, \mathrm{~B} 9$ & $\mathrm{~B} 5$ & \\
$\mathrm{~B} 6$ & $\mathrm{~B} 3, \mathrm{~B} 4, \mathrm{~B} 6$ & $\mathrm{~B} 1, \mathrm{~B} 2, \mathrm{~B} 5, \mathrm{~B} 6, \mathrm{~B} 7, \mathrm{~B} 8, \mathrm{~B} 9$ & \\
$\mathrm{~B} 7$ & $\mathrm{~B} 3, \mathrm{~B} 4, \mathrm{~B} 6, \mathrm{~B} 7$ & $\mathrm{~B} 1, \mathrm{~B} 2, \mathrm{~B} 5, \mathrm{~B} 7, \mathrm{~B} 8, \mathrm{~B} 9$ & \\
$\mathrm{~B} 8$ & $\mathrm{~B} 1, \mathrm{~B} 3, \mathrm{~B} 4, \mathrm{~B} 6, \mathrm{~B} 7, \mathrm{~B} 8$ & $\mathrm{~B} 1, \mathrm{~B} 2, \mathrm{~B} 5, \mathrm{~B} 8, \mathrm{~B} 9$ & \\
$\mathrm{~B} 9$ & $\mathrm{~B} 1, \mathrm{~B} 3, \mathrm{~B} 4, \mathrm{~B} 6, \mathrm{~B} 7, \mathrm{~B} 8, \mathrm{~B} 9$ & $\mathrm{~B} 2, \mathrm{~B} 5, \mathrm{~B} 9$ & \\
\hline
\end{tabular}


Table A2. Level partition iteration II

\begin{tabular}{cccc}
\hline Barriers & Reachability Set $\mathbf{R}\left(\mathbf{B}_{\mathbf{i}}\right)$ & Antecedent Set A $\left(\mathbf{B}_{\mathbf{i}}\right)$ & Intersection Set $\mathbf{R}\left(\mathbf{B}_{\mathbf{i}}\right) \cap \mathbf{A}\left(\mathbf{B}_{\mathbf{i}}\right)$ \\
\hline $\mathrm{B} 1$ & $\mathrm{~B} 1, \mathrm{~B} 6, \mathrm{~B} 7, \mathrm{~B} 8$ & $\mathrm{~B} 1, \mathrm{~B} 2, \mathrm{~B} 5, \mathrm{~B} 8, \mathrm{~B} 9$ & \\
$\mathrm{~B} 2$ & $\mathrm{~B} 1, \mathrm{~B} 2, \mathrm{~B} 5, \mathrm{~B} 6, \mathrm{~B} 7, \mathrm{~B} 8, \mathrm{~B} 9$ & $\mathrm{~B} 2, \mathrm{~B} 5$ & \\
$\mathrm{~B} 5$ & $\mathrm{~B} 1, \mathrm{~B} 2, \mathrm{~B} 5, \mathrm{~B} 6, \mathrm{~B} 7, \mathrm{~B} 8, \mathrm{~B} 9$ & $\mathrm{~B} 2, \mathrm{~B} 5$ & $\mathrm{~B} 6$ \\
$\mathrm{~B} 6$ & $\mathrm{~B} 6$ & $\mathrm{~B} 1, \mathrm{~B} 2, \mathrm{~B} 5, \mathrm{~B} 6, \mathrm{~B} 7, \mathrm{~B} 8, \mathrm{~B} 9$ & $\mathrm{II}$ \\
$\mathrm{B} 7$ & $\mathrm{~B} 6, \mathrm{~B} 7$ & $\mathrm{~B} 1, \mathrm{~B} 2, \mathrm{~B} 5, \mathrm{~B} 7, \mathrm{~B} 8, \mathrm{~B} 9$ & \\
$\mathrm{~B} 8$ & $\mathrm{~B} 1, \mathrm{~B} 6, \mathrm{~B} 7, \mathrm{~B} 8$ & $\mathrm{~B} 1, \mathrm{~B} 2, \mathrm{~B} 5, \mathrm{~B} 8, \mathrm{~B} 9$ & \\
$\mathrm{~B} 9$ & $\mathrm{~B} 1, \mathrm{~B} 6, \mathrm{~B} 7, \mathrm{~B} 8, \mathrm{~B} 9$ & $\mathrm{~B} 2, \mathrm{~B} 5, \mathrm{~B} 9$ & \\
\hline
\end{tabular}

Table A3. Level partition iteration III.

\begin{tabular}{|c|c|c|c|c|}
\hline Barriers & Reachability Set R $\left(B_{i}\right)$ & Antecedent Set A ( $\left.\mathbf{B}_{\mathbf{i}}\right)$ & Intersection Set $R\left(B_{i}\right) \cap A\left(B_{i}\right)$ & Level \\
\hline B1 & $\mathrm{B} 1, \mathrm{~B} 7, \mathrm{~B} 8$ & B1,B2,B5,B8,B9 & & \\
\hline B2 & $\mathrm{B} 1, \mathrm{~B} 2, \mathrm{~B} 5, \mathrm{~B} 7, \mathrm{~B} 8, \mathrm{~B} 9$ & B2,B5 & & \\
\hline B5 & $\mathrm{B} 1, \mathrm{~B} 2, \mathrm{~B} 5, \mathrm{~B} 7, \mathrm{~B} 8, \mathrm{~B} 9$ & B2,B5 & & \\
\hline B7 & B7 & $\mathrm{B} 1, \mathrm{~B} 2, \mathrm{~B} 5, \mathrm{~B} 7, \mathrm{~B} 8, \mathrm{~B} 9$ & B7 & III \\
\hline B8 & B1,B7,B8 & B1,B2,B5,B8,B9 & & \\
\hline B9 & $\mathrm{B} 1, \mathrm{~B} 7, \mathrm{~B} 8, \mathrm{~B} 9$ & B2,B5,B9 & & \\
\hline
\end{tabular}

Table A4. Level partition iteration IV.

\begin{tabular}{|c|c|c|c|c|}
\hline Barriers & Reachability Set $R\left(B_{i}\right)$ & Antecedent Set $A\left(B_{i}\right)$ & Intersection Set $\mathbf{R}\left(\mathbf{B}_{\mathbf{i}}\right) \cap \mathbf{A}\left(\mathbf{B}_{\mathbf{i}}\right)$ & Level \\
\hline B1 & $\mathrm{B} 1, \mathrm{~B} 8$ & B1,B2,B5,B8,B9 & $\mathrm{B} 1, \mathrm{~B} 8$ & IV \\
\hline $\mathrm{B} 2$ & $\mathrm{~B} 1, \mathrm{~B} 2, \mathrm{~B} 5, \mathrm{~B} 8, \mathrm{~B} 9$ & B2,B5 & & \\
\hline B5 & $\mathrm{B} 1, \mathrm{~B} 2, \mathrm{~B} 5, \mathrm{~B} 8, \mathrm{~B} 9$ & B2,B5 & & \\
\hline B8 & B1,B8 & $\mathrm{B} 1, \mathrm{~B} 2, \mathrm{~B} 5, \mathrm{~B} 8, \mathrm{~B} 9$ & B1, B8 & IV \\
\hline B9 & B1,B8,B9 & B2,B5,B9 & & \\
\hline
\end{tabular}

Table A5. Level partition iteration V \& VI.

\begin{tabular}{ccccc}
\hline Barriers & Reachability Set $\mathbf{R}\left(\mathbf{B}_{\mathbf{i}}\right)$ & Antecedent Set A $\left.\mathbf{( B}_{\mathbf{i}}\right)$ & Intersection Set $\mathbf{R}\left(\mathbf{B}_{\mathbf{i}}\right) \cap \mathbf{A}\left(\mathbf{B}_{\mathbf{i}}\right)$ & Level \\
\hline B2 & B2,B5 & B2,B5 & B2,B5 & VI \\
B5 & B2,B5 & B2,B5 & B2,B5 & VI \\
B9 & B9 & B2,B5,B9 & B9 & V \\
\hline
\end{tabular}

\section{References}

1. Behl, A.; Pal, A. Analysing the barriers towards sustainable financial inclusion using mobile banking in rural India. Indian J. Sci. Technol. 2016, 9, 1-7. [CrossRef]

2. Nambiar, B.K.; Ramanathan, H.N.; Rana, S.; Prashar, S. Perceived service quality and customer satisfaction: A missing link in Indian banking sector. Vision 2018, 23, 44-55. [CrossRef]

3. Zhu, Y.; Freeman, S.; Cavusgil, S.T. Service quality delivery in a cross-national context. Int. Bus. Rev. 2018, 27, 1022-1032. [CrossRef]

4. Van Loo, R. Making innovation more competitive: The case of Fintech. UCLA Law Rev. 2018, 65, 232.

5. Bueno, E.V.; Weber, T.B.B.; Bomfim, E.L.; Kato, H.T. Measuring customer experience in service: A systematic review. Serv. Ind. J. 2019, 39, 779-798. [CrossRef]

6. Shankar, A.; Jebarajakirthy, C. The influence of e-banking service quality on customer loyalty. Int. J. Bank Market. 2019, 37, 1119-1142. [CrossRef]

7. Heirati, N.; O'Cass, A.; Schoefer, K.; Siahtiri, V. Do professional service firms benefit from customer and supplier collaborations in competitive, turbulent environments? Ind. Mark. Manag. 2016, 55, 50-58. [CrossRef]

8. Paujik, Y.M.; Miller, M.; Gibson, M.; Walsh, K. 'Doing'socio-political sustainability in early childhood: Teacher-as-researcher reflective practices. Glob. Stud. Child. 2020. [CrossRef]

9. Chen, L.; Zhao, X.; Tang, O.; Price, L.; Zhang, S.; Zhu, W. Supply chain collaboration for sustainability: A literature review and future research agenda. Int. J. Prod. Econ. 2017, 194, 73-87. [CrossRef]

10. Klarin, T. The concept of sustainable development: From its beginning to the contemporary issues. Zagreb Int. Rev. Econ. Bus. 2018, 21, 67-94. [CrossRef] 
11. Palacios-Marques, D.; Guijarro, M.; Carrilero, A. The use of customer-centric philosophy in hotels to improve customer loyalty. J. Bus. Ind. Mark. 2016, 31, 339-348. [CrossRef]

12. Laari, S.; Töyli, J.; Ojala, L. The effect of a competitive strategy and green supply chain management on the financial and environmental performance of logistics service providers. Bus. Strategy Environ. 2018, 27, 872-883. [CrossRef]

13. Hussain, M.; Ajmal, M.M.; Gunasekaran, A.; Khan, M. Exploration of social sustainability in healthcare supply chain. J. Clean. Prod. 2018, 203, 977-989. [CrossRef]

14. Blair, H. Citizen Participation and Political Accountability for Public Service Delivery in India: Remapping the World Bank's Routes. J. South Asian Dev. 2018, 13, 54-81. [CrossRef]

15. Centobelli, P.; Cerchione, R.; Esposito, E. Environmental sustainability in the service industry of transportation and logistics service providers: Systematic literature review and research directions. Transp. Res. Part D Transp. Environ. 2017, 53, 454-470. [CrossRef]

16. Zhao, Q.; Tsai, P.H.; Wang, J.L. Improving financial service innovation strategies for enhancing china's banking industry competitive advantage during the fintech revolution: A Hybrid MCDM model. Sustainability 2019, 11, 1419. [CrossRef]

17. Adebanjo, D.; Teh, P.L.; Ahmed, P.K. The impact of supply chain relationships and integration on innovative capabilities and manufacturing performance: The perspective of rapidly developing countries. Int. J. Prod. Res. 2018, 56, 1708-1721. [CrossRef]

18. Chatterjee, E. The politics of electricity reform: Evidence from West Bengal, India. World Dev. 2018, 104, 128-139. [CrossRef]

19. Sinha, A. India's Unlikely Democracy: Economic Growth and Political Accommodation. J. Democr. 2007, 18, 41-54. [CrossRef]

20. Sochor, J.; Arby, H.; Karlsson, I.M.; Sarasini, S. A topological approach to Mobility as a Service: A proposed tool for understanding requirements and effects, and for aiding the integration of societal goals. Res. Transp. Bus. Manag. 2018, 27, 3-14. [CrossRef]

21. Cherp, A.; Vinichenko, V.; Jewell, J.; Brutschin, E.; Sovacool, B. Integrating techno-economic, socio-technical and political perspectives on national energy transitions: A meta-theoretical framework. Energy Res. Soc. Sci. 2018, 37, 175-190. [CrossRef]

22. Sroufe, R.; Gopalakrishna-Remani, V. Management, social sustainability, reputation, and financial performance relationships: An empirical examination of US firms. Organ. Environ. 2019, 32, 331-362. [CrossRef]

23. Alvarez-Sousa, A. The problems of tourist sustainability in cultural cities: Socio-political perceptions and interests management. Sustainability 2018, 10, 503. [CrossRef]

24. Rock, M.; Murphy, J.T.; Rasiah, R.; van Seters, P.; Managi, S. A hard slog, not a leap frog: Globalization and sustainability transitions in developing Asia. Technol. Forecast. Soc. Chang. 2009, 76, 241-254. [CrossRef]

25. Golicic, S.L.; Lenk, M.M.; Hazen, B.T. A global meaning of supply chain social sustainability. Prod. Plan. Control 2020, 31, 988-1004. [CrossRef]

26. Puroila, J.; Mäkelä, H. Matter of opinion: Exploring the socio-political nature of materiality disclosures in sustainability reporting. Account. Audit. Account. J. 2019, 32, 1043-1072. [CrossRef]

27. Shirodkar, V.; Beddewela, E.; Richter, U.H. Firm-level determinants of political CSR in emerging economies: Evidence from India. J. Bus. Ethics 2018, 148, 673-688. [CrossRef]

28. Vieira, B.D.O.; Guarnieri, P.; Camara, S.L.; Alfinito, S. Prioritizing Barriers to Be Solved to the Implementation of Reverse Logistics of E-Waste in Brazil under a Multicriteria Decision Aid Approach. Sustainability 2020, 12, 4337. [CrossRef]

29. Van der Have, R.P.; Rubalcaba, L. Social innovation research: An emerging area of innovation studies? Res. Policy 2016, 45, 1923-1935. [CrossRef]

30. Mani, V.; Gunasekaran, A.; Papadopoulos, T.; Hazen, B.; Dubey, R. Supply chain social sustainability for developing nations: Evidence from India. Resour. Conserv. Recycl. 2016, 111, 42-52. [CrossRef]

31. Yadav, R.; Pathak, G. Environmental sustainability through green banking: A study on private and public sector banks in India. Oida Int. J. Sustain. Dev. 2013, 6, 37-48.

32. Katiyar, R.; Badola, S. Modelling the barriers to online banking in the Indian scenario: An ISM approach. J. Model. Manag. 2018, 13, 550-569. [CrossRef]

33. Behl, A.; Singh, M.; Venkatesh, V.G. Enablers and barriers of mobile banking opportunities in rural India: A strategic analysis. Int. J. Bus. Excel. 2016, 10, 209-239. [CrossRef]

34. Smith, A.; Stirling, A. The Politics of Social-ecological Resilience and Sustainable Socio-technical Transitions. Ecol. Soc. 2010, 15, 1. Available online: http:/ / www.jstor.org/stable/26268112 (accessed on 10 September 2020). [CrossRef]

35. Vormedal, I.; Ruud, A. Sustainability reporting in Norway-an assessment of performance in the context of legal demands and socio-political drivers. Bus. Strategy Environ. 2009, 18, 207-222. [CrossRef]

36. Patterson, J.; Schulz, K.; Vervoort, J.; Van Der Hel, S.; Widerberg, O.; Adler, C.; Barau, A. Exploring the governance and politics of transformations towards sustainability. Environ. Innov. Soc. Transit. 2017, 24, 1-16. [CrossRef]

37. Wüstenhagen, R.; Wolsink, M.; Bürer, M.J. Social acceptance of renewable energy innovation: An introduction to the concept. Energy Policy 2007, 35, 2683-2691. [CrossRef]

38. Tarrant, S.P.; Thiele, L.P. Practice makes pedagogy-John Dewey and skills-based sustainability education. Int. J. Sustain. High. Educ. 2016, 17, 54-67. [CrossRef]

39. Ahmadi, H.B.; Kusi-Sarpong, S.; Rezaei, J. Assessing the social sustainability of supply chains using Best Worst Method. Resour. Conserv. Recycl. 2017, 126, 99-106. [CrossRef]

40. Khan, S.A.R.; Sharif, A.; Golpîra, H.; Kumar, A. A green ideology in Asian emerging economies: From environmental policy and sustainable development. Sustain. Dev. 2019, 27, 1063-1075. [CrossRef] 
41. Diaz-Sarachaga, J.M.; Jato-Espino, D.; Castro-Fresno, D. Methodology for the development of a new Sustainable Infrastructure Rating System for Developing Countries (SIRSDEC). Environ. Sci. Policy 2017, 69, 65-72. [CrossRef]

42. Bouzon, M.; Govindan, K.; Rodriguez, C.M.T.; Campos, L.M. Identification and analysis of reverse logistics barriers using fuzzy Delphi method and AHP. Resour. Conserv. Recycl. 2016, 108, 182-197. [CrossRef]

43. Moktadir, M.A.; Ali, S.M.; Rajesh, R.; Paul, S.K. Modeling the interrelationships among barriers to sustainable supply chain management in leather industry. J. Clean. Prod. 2018, 181, 631-651. [CrossRef]

44. Hobson, K.; Lynch, N. Ecological modernization, techno-politics and social life cycle assessment: A view from human geography. Int. J. Life Cycle Assess. 2018, 23, 456-463. [CrossRef]

45. Waas, T.; Hugé, J.; Verbruggen, A.; Wright, T. Sustainable development: A bird's eye view. Sustainability 2011, 3, 1637-1661. [CrossRef]

46. Elliott, A. Beck's sociology of risk: A critical assessment. Sociology 2002, 36, 293-315. [CrossRef]

47. Reddy, A.K. Indian power sector reform for sustainable development: The public benefits imperative. Energy Sustain. Dev. 2001, 5, 74-81. [CrossRef]

48. Garrett, J.L. Achieving Urban Food and Nutrition Security in the Developing World (No. 571-2016-39077). 2000. Available online: http:/ /ageconsearch.umn.edu/record/16037 (accessed on 31 August 2000). [CrossRef]

49. Fukuda-Parr, S. From the Millennium Development Goals to the Sustainable Development Goals: Shifts in purpose, concept, and politics of global goal setting for development. Gend. Dev. 2016, 24, 43-52. [CrossRef]

50. Benatar, S. Politics, power, poverty and global health: Systems and frames. Int. J. Health Policy Manag. 2016, 5, 599. [CrossRef]

51. OECD. Development Co-operation Report 2020: Learning from Crises, Building Resilience; OECD Publishing: Paris, France; Available online: https://www.oecd-ilibrary.org/development/development-co-operation-report-2020_f6d42aa5-en (accessed on 22 December 2020).

52. Overman, S. Great expectations of public service delegation: A systematic review. Public Manag. Rev. 2016, 18, 1238-1262. [CrossRef]

53. Chen, I.J.; Kitsis, A.M. A research framework of sustainable supply chain management: The role of relational capabilities in driving performance. Int. J. Logist. Manag. 2017, 28, 1454-1478. [CrossRef]

54. Dobler, M.; Lajili, K.; Zéghal, D. Corporate environmental sustainability disclosures and environmental risk: Alternative tests of socio-political theories. J. Account. Organ. Chang. 2015. [CrossRef]

55. Avelino, F.; Grin, J.; Pel, B.; Jhagroe, S. The politics of sustainability transitions. J. Environ. Policy Plan. 2016, 18, 557-567. [CrossRef]

56. Dasgupta, P. The economics of common property resources: A dynamic formulation of the fisheries problem. Indian Econ. Rev. 2019, 54, 19-44. [CrossRef]

57. Xiao, L. Analyzing consumer online group buying motivations: An interpretive structural modeling approach. Telemat. Inf. 2018 35, 629-642. [CrossRef]

58. Perez-Foguet, A.; Lazzarini, B.; Giné, R.; Velo, E.; Boni, A.; Sierra, M.; Trimingham, R. Promoting sustainable human development in engineering: Assessment of online courses within continuing professional development strategies. J. Clean. Prod. 2018, 172, 4286-4302. [CrossRef]

59. Garcia, S.; Cintra, Y.; Rita de Cássia, S.R.; Lima, F.G. Corporate sustainability management: A proposed multi-criteria model to support balanced decision-making. J. Clean. Prod. 2016, 136, 181-196. [CrossRef]

60. Mani, V.; Agrawal, R.; Sharma, V. Supplier selection using social sustainability: AHP based approach in India. Int. Strateg. Manag. Rev. 2014, 2, 98-112. [CrossRef]

61. Kagawa, F. Dissonance in students' perceptions of sustainable development and sustainability: Implications for curriculum change. Int. J. Sustain. High. Educ. 2007, 8, 317-338. [CrossRef]

62. Köhler, J.; Geels, F.W.; Kern, F.; Markard, J.; Onsongo, E.; Wieczorek, A.; Wells, P. An agenda for sustainability transitions research: State of the art and future directions. Environ. Innov. Soc. Transit. 2019, 31, 1-32. [CrossRef]

63. Zeng, H.; Chen, X.; Xiao, X.; Zhou, Z. Institutional pressures, sustainable supply chain management, and circular economy capability: Empirical evidence from Chinese eco-industrial park firms. J. Clean. Prod. 2017, 155, 54-65. [CrossRef]

64. Chang, R.D.; Zuo, J.; Zhao, Z.Y.; Zillante, G.; Gan, X.L.; Soebarto, V. Evolving theories of sustainability and firms: History, future directions and implications for renewable energy research. Renew. Sustain. Energy Rev. 2017, 72, 48-56. [CrossRef]

65. Utting, P. Social and political dimensions of environmental protection in Central America. Dev. Chang. 1994, 25, 231-259. [CrossRef]

66. Pellegrino, R.; Carbonara, N.; Costantino, N. Public guarantees for mitigating interest rate risk in PPP projects. Built Environ. Proj. Asset Manag. 2019, 9, 248-261. [CrossRef]

67. Županović, I. Sustainable risk management in the banking sector. J. Cent. Bank. Theory Pract. 2014, 3, 81-100.

68. Chandra Das, S. Status and direction of corporate social responsibility in Indian perspective: An exploratory study. Soc. Responsib. J. 2009, 5, 34-47. [CrossRef]

69. Yadav, N.; Gupta, K.; Rani, L.; Rawat, D. Drivers of sustainability practices and SMEs: A systematic literature review. Eur. J. Sustain. Dev. 2018, 7, 531. [CrossRef]

70. Kadavil, S.M. Private Labelling, Governance, and Sustainability: An Analysis of the Tea Industry in India. In Business Responsibility and Sustainability in India; Palgrave Macmillan: Cham, Switzerland, 2019; pp. 221-240. [CrossRef] 
71. Mugova, S.; Mudenda, M.; Sachs, P.R. Corporate social responsibility in challenging times in developing countries. In Corporate Social Responsibility in Times of Crisis; Springer: Cham, Switzerland, 2017; pp. 207-228. [CrossRef]

72. Kedar, B.A.O. The Power of Synthesis: The Pursuit of Environmental Sustainability and Social Equity through Design Practice. Ph.D. Thesis, University of Maryland, College Park, MD, USA, 2017. [CrossRef]

73. Maes, J.; Molombe, J.M.; Mertens, K.; Parra, C.; Poesen, J.; Che, V.B.; Kervyn, M. Socio-political drivers and consequences of landslide and flood risk zonation: A case study of Limbe city, Cameroon. Environ. Plan. C Politics Space 2019, 37, 707-731. [CrossRef]

74. Koh, S.L.; Gunasekaran, A.; Morris, J.; Obayi, R.; Ebrahimi, S.M. Conceptualizing a circular framework of supply chain resource sustainability. Int. J. Oper. Prod. Manag. 2017, 37, 1520-1540. [CrossRef]

75. Wu, G.C. Effects of socially responsible supplier development and sustainability-oriented innovation on sustainable development: Empirical evidence from SMEs. Corp. Soc. Responsib. Environ. Manag. 2017, 24, 661-675. [CrossRef]

76. Marques, P.; Bernardo, M.; Presas, P.; Simon, A. Corporate social responsibility in a local subsidiary: Internal and external stakeholders' power. Eur. Med. J. Bus. 2019, 15, 377-393. [CrossRef]

77. Mathivathanan, D.; Kannan, D.; Haq, A.N. Sustainable supply chain management practices in Indian automotive industry: A multi-stakeholder view. Resour. Conserv. Recycl. 2018, 128, 284-305. [CrossRef]

78. Mani, V.; Gunasekaran, A.; Delgado, C. Enhancing supply chain performance through supplier social sustainability: An emerging economy perspective. Int. J. Prod. Econ. 2018, 195, 259-272. [CrossRef]

79. Varkkey, H.; Tyson, A.; Choiruzzad, S.A.B. Palm oil intensification and expansion in Indonesia and Malaysia: Environmental and socio-political factors influencing policy. For. Policy Econ. 2018, 92, 148-159. [CrossRef]

80. Kumar, D.; Goyal, P.; Kumar, V. Prioritizing CSR barriers in the Indian service industry: A fuzzy AHP approach. Sci. Ann. Econ. Bus. 2019, 66, 213-233.

81. Chlela, M. Corporate Social Responsibility Practices in the Lebanese Banking Sector: A Reality or a Myth? Ph.D. Thesis, Notre Dame University-Louaize, Zouk Mosbeh, Lebanon, 2020.

82. Mura, M.; Longo, M.; Micheli, P.; Bolzani, D. The evolution of sustainability measurement research. Int. J. Manag. Rev. 2018, 20, 661-695. [CrossRef]

83. Kanji, R.; Agrawal, R. Building a society conducive to the use of corporate social responsibility as a tool to develop disaster resilience with sustainable development as the goal: An interpretive structural modelling approach in the Indian context. Asian J. Sustain. Soc. Responsib. 2019, 4, 5. [CrossRef]

84. Vidhya, B. CSR Reporting Practices in Indian Private Sector Banks. Sumedha J. Manag. 2018, 7, $29-37$.

85. Kumar, K.; Prakash, A. Developing a framework for assessing sustainable banking performance of the Indian banking sector. Soc. Responsib. J. 2019, 15, 689-709. [CrossRef]

86. Dawood, A.S.M.; Eldahan, O.H. Assessing the Level of Sustainability in the Egyptian Banking Sector. Eur. J. Bus. Manag. Res. 2020, 5. [CrossRef]

87. Yüksel, S. Determinants of the credit risk in developing countries after economic crisis: A case of Turkish banking sector. In Global Financial Crisis and its Ramifications on Capital Markets; Springer: Cham, Switzerland, 2017; pp. 401-415.

88. Aneja, R.; Ahuja, V. An assessment of socioeconomic impact of COVID-19 pandemic in India. J. Public Aff. 2020, e2266. [CrossRef] [PubMed]

89. Feldmann, H. Banking deregulation around the world, 1970s to 2000s: The impact on unemployment. Int. Rev. Econ. Financ. 2012, 24, 26-42. [CrossRef]

90. Biswas, T.K.; Das, M.C. Selection of the barriers of supply chain management in Indian manufacturing sectors due to COVID-19 impacts. Oper. Res. Eng. Sci. Theory Appl. 2020, 3, 1-12. [CrossRef]

91. Goel, R.K.; Saunoris, J.W. Unemployment and international shadow economy: Gender differences. Appl. Econ. 2017, 49, 5828-5840. [CrossRef]

92. Yasmin, M.; Naseem, F.; Masso, I.C. Teacher-directed learning to self-directed learning transition barriers in Pakistan. Stud. Educ. Eval. 2019, 61, 34-40. [CrossRef]

93. Maisuria, A. Neoliberal development and struggle against it: The importance of social class, mystification and feasibility. Aula Abierta 2018, 47, 433-440. [CrossRef]

94. Marshall, C.A. Barriers to Accessing Higher Education. In Widening Participation, Higher Education and Non-Traditional Students; Palgrave Macmillan: London, UK, 2016; pp. 1-18.

95. Muchangos, L.S.; Tokai, A.; Hanashima, A. Analyzing the structure of barriers to municipal solid waste management policy planning in Maputo city, Mozambique. Environ. Dev. 2015, 16, 76-89. [CrossRef]

96. Khaba, S.; Bhar, C. Analysing the barriers of lean in Indian coal mining industry using integrated ISM-MICMAC and SEM. Benchmarking Int. J. 2018, 25, 2145-2168. [CrossRef]

97. Hussain, K.; He, Z.; Ahmad, N.; Iqbal, M. Green, lean, six sigma barriers at a glance: A case from the construction sector of Pakistan. Build. Environ. 2019, 161, 106225. [CrossRef]

98. Prakash, C.; Barua, M.K. Flexible modelling approach for evaluating reverse logistics adoption barriers using fuzzy AHP and IRP framework. Int. J. Oper. Res. 2017, 30, 151-171. [CrossRef]

99. Vinodh, S.; Asokan, P. ISM and Fuzzy MICMAC application for analysis of Lean Six Sigma barriers with environmental considerations. Int. J. Lean Six Sigma 2018, 9, 64-90. [CrossRef] 
100. Al-Hanawi, M.K.; Almubark, S.; Qattan, A.M.; Cenkier, A.; Kosycarz, E.A. Barriers to the implementation of public-private partnerships in the healthcare sector in the Kingdom of Saudi Arabia. PLoS ONE 2020, 15, e0233802.

101. Sindhu, S.; Nehra, V.; Luthra, S. Identification and analysis of barriers in implementation of solar energy in Indian rural sector using integrated ISM and fuzzy MICMAC approach. Renew. Sustain. Energy Rev. 2016, 62, 70-88. [CrossRef]

102. Govindan, K.; Shankar, K.M.; Kannan, D. Achieving sustainable development goals through identifying and analyzing barriers to industrial sharing economy: A framework development. Int. J. Prod. Econ. 2020, 227, 107575. [CrossRef]

103. Rosso-Cerón, A.M.; Kafarov, V. Barriers to social acceptance of renewable energy systems in Colombia. Curr. Opin. Chem. Eng. 2015, 10, 103-110. [CrossRef]

104. Sengar, A.; Sharma, V.; Agrawal, R.; Dwivedi, A.; Dwivedi, P.; Joshi, K.; Barthwal, M. Prioritization of barriers to energy generation using pine needles to mitigate climate change: Evidence from India. J. Clean. Prod. 2020, 275, 123840. [CrossRef]

105. Roy, A.; Sekhar, C.; Vyas, V. Barriers to internationalization: A study of small and medium enterprises in India. J. Int. Entrep. 2016, 14, 513-538. [CrossRef]

106. Talib, F.; Rahman, Z. Modeling the barriers of Indian telecom services using ISM and MICMAC approach. J. Asia Bus. Stud. 2017, 11, 188-209. [CrossRef]

107. Mikkelsen, M.H.; Kristensen, M.A.N.; Wenzel, K.; Agustín, L.S.R. Barriers for Economic, Political and Social Empowerment in Relation to Financial Inclusion of Urban Women Workers in Faridabad. Master Thesis, Aalborg University, Aalborg, Denmark, 2019; pp. 1-120.

108. Battams, S.; Townsend, B. Power asymmetries, policy incoherence and noncommunicable disease control-a qualitative study of policy actor views. Crit. Public Health 2019, 29, 596-609. [CrossRef]

109. Kumar, S.; Malhotra, V.; Kumar, V. Identification of key barriers affecting the cellular manufacturing system by ISM approach. Int. J. Process Manag. Benchmarking 2017, 7, 466-486. [CrossRef]

110. Sushil "Modified ISM/TISM process with simultaneous transitivity checks for reducing paired comparisons". Glob. J. Flex. Syst. Manag. 2017, 18, 331-351. [CrossRef]

111. Kumar, K.; Dhillon, V.S.; Singh, P.L.; Sindhwani, R. Modeling and analysis for barriers in healthcare services by ISM and MICMAC analysis. In Advances in Interdisciplinary Engineering; Springer: Singapore, 2019; pp. 501-510. [CrossRef]

112. Rastrollo-Horrillo, M.A.; Rivero Díaz, M. Destination social capital and innovation in SMEs tourism firms: An empirical analysis in an adverse socio-economic context. J. Sustain. Tour. 2019, 27, 1572-1590. [CrossRef]

113. Vargas, C.L.; García, J.L. Evaluating the impact of ERP systems on SC performance with ISM. Wpom-Work. Pap. Oper. Manag. 2017, 8, 101-103. [CrossRef]

114. Raut, R.; Narkhede, B.E.; Gardas, B.B.; Luong, H.T. An ISM approach for the barrier analysis in implementing sustainable practices. Benchmarking Int. J. 2018. [CrossRef]

115. Dwivedi, G.; Srivastava, S.K.; Srivastava, R.K. Analysis of barriers to implement additive manufacturing technology in the Indian automotive sector. Int. J. Phys. Distrib. Logist. Manag. 2017. [CrossRef]

116. Narayanan, A.E.; Sridharan, R.; Kumar, P.R. Analyzing the interactions among barriers of sustainable supply chain management practices. J. Manuf. Technol. Manag. 2019, 30, 937-971. [CrossRef]

117. Menon, S.; Suresh, M. Total interpretive structural modelling: Evolution and applications. In International Conference on Innovative Data Communication Technologies and Application; Springer: Cham, Switzerland, 2019; pp. 257-265.

118. Roshani, K.; Owlia, M.S.; Abooie, M.H. A research note on the article of "Quality framework in education through application of interpretive structural modeling". Tqm J. 2019, 31, 3-10. [CrossRef]

119. Jayant, A.; Azhar, M. Analysis of the barriers for implementing green supply chain management (GSCM) practices: An interpretive structural modeling (ISM) approach. Procedia Eng. 2014, 97, 2157-2166. [CrossRef]

120. Daneshgar, M.; Abdolvand, M.A.; Heidarzadeh Henzaei, K.; Khoon Siavash, M. Modeling Corporate Brand Identity in the Banking Industry. J. Bus. Manag. 2020, 12, 652-678.

121. Bux, H.; Zhang, Z.; Ahmad, N. Promoting sustainability through corporate social responsibility implementation in the manufacturing industry: An empirical analysis of barriers using the ISM-MICMAC approach. Corp. Soc. Responsib. Environ. Manag. 2020, 1-20. [CrossRef]

122. Sharma, M.; Joshi, S. Barriers to blockchain adoption in health-care industry: An Indian perspective. J. Glob. Oper. Strat. Sourc. 2021. [CrossRef]

123. Narwane, V.S.; Yadav, V.S.; Raut, R.D.; Narkhede, B.E.; Gardas, B.B. Sustainable development challenges of the biofuel industry in India based on integrated MCDM approach. Renew. Energy 2021, 164, 298-309. [CrossRef]

124. Baliga, A.J.; Chawla, V.; Sunder, M.V.; Kumar, R. Barriers to service recovery in B2B markets: A TISM approach in the context of IT-based services. J. Bus. Ind. Mark. 2021. [CrossRef]

125. Agarwal, S.; Tyagi, M.; Garg, R.K. Assessment of Barriers of Green Supply Chain Management Using Structural Equation Modeling. In Recent Advances in Mechanical Engineering; Springer: Singapore, 2021; pp. 441-452.

126. Rizvi, N.U.; Kashiramka, S.; Singh, S.; Sushil. A hierarchical model of the determinants of non-performing assets in banks: An ISM and MICMAC approach. Appl. Econ. 2019, 51, 3834-3854. [CrossRef]

127. Rehman, A.U.; Al-Zabidi, A.; AlKahtani, M.; Umer, U.; Usmani, Y.S. Assessment of Supply Chain Agility to Foster Sustainability: Fuzzy-DSS for a Saudi Manufacturing Organization. Processes 2020, 8, 577. [CrossRef] 
128. Cubric, M. Drivers, barriers and social considerations for AI adoption in business and management: A tertiary study. Technol. Soc. 2020, 62, 101257. [CrossRef]

129. Lo, A.Y. Active conflict or passive coherence? The political economy of climate change in China. Environ. Politics 2010, 19, 1012-1017. [CrossRef]

130. Duclos, L.K.; Vokurka, R.J.; Lummus, R.R. A conceptual model of supply chain flexibility. Ind. Manag. Data Syst. 2003, 103, 446-456. [CrossRef]

131. Shibin, K.T.; Dubey, R.; Gunasekaran, A.; Luo, Z.; Papadopoulos, T.; Roubaud, D. Frugal innovation for supply chain sustainability in SMEs: Multi-method research design. Prod. Plan. Control 2018, 29, 908-927. [CrossRef] 